\title{
Youth Enterprise Development Funds Services and Youth Empowerment in
} Wajir County, Kenya

\author{
Hassan Adow Mohamud ${ }^{1}$, Dr. Fredrick Ndede ${ }^{2}$ \\ ${ }^{1}$ Correspondent Author, MBA Finance Student, School of Business, Kenyatta University, Kenya \\ ${ }^{2}$ Department of Accounting and Finance School of Business Kenyatta University, Kenya
}

ABSTRACT

Youth empowerment is vital for any nation. Most Kenyan youths aspire to get white-collar jobs after completing education in order to build self and the nation. To most, achieving their career goals after the 8-4-4 education system is the most critical thing hence they will not settle for anything less than what they have trained for. The Government of Kenya has made efforts over the years to empower the youth by coming up with policies that enable the youth to venture in education as well as create opportunity for income generating projects. It is on this basis that this study therefore sought to examine the effect of YEDF services on youth empowerment in Wajir County. The study objectives were: to assess the effect of YEDF entrepreneurial training on job creation, to examine the effect of YEDF provision of loans on income and to determine the effect of YEDF provision of market linkages on youth enterprise development in Wajir County. The study adopted social capital, theory of change and reform theory to assess relationship among the various factors that have been identified as important to the study problem. This study adopted the descriptive survey research design. The target population of the study consists of the 200 youth groups in Wajir County. This study used a closed and open - ended questionnaire to administer to the sample since time may be limited and information needed could easily be described in writing. The data was coded and entered on a Statistical Package for Social Science (SPSS) software that aids in analysis of both qualitative and quantitative data. The researcher adopted content analysis to analyse the qualitative data based on the objectives. The descriptive statistics was used in analysing quantitative data. The researcher adopted content analysis to analyse the qualitative data based on the objectives. The descriptive statistics was used in analysing quantitative data. In analysing the relationship between variable (YEDF services and youth empowerment) the study used regression analysis. The study found out that attending the entrepreneurship training is important in improving business performance. The youths are trained on ways of improving and retaining customers. The researcher found out that most youths in the county have loan accessibility and have been accessing it for the past one year. The study found out that most youths have attended market linkages program. By attending the programs, they have learnt various ways of improving their business performance and sharing of business ideas. Finally, the study found out that there is a significant relationship between market linkages and youth's empowerment in the County. The study recommended that the government and stakeholders to promote entrepreneur training, offering of loans and market linkages to equip youths with business skills. The study took a year to be completed, the researcher started in June 2017 and ended in July 2018.

Key Words: Youth Enterprise, Youth Enterprise Development Funds Services, Youth Empowerment

DOI: 10.7176/ijcab.v3iII.23, URN nbn:de:0000ijcab.v3iII.236 


\section{Cite this Article:}

Mohamud, H., \& Ndede, F. (2019). Youth Enterprise Development Funds Services and Youth Empowerment in Wajir County, Kenya. International Journal of Current Aspects, 3(II), 280-292. http://journals.ijcab.org/journals/index.php/ijcab/article/view/23

\section{INTRODUCTION}

The world youth report stated that of 160 million unemployed people globally, the youth represented $40 \%$ of them (Thiongo, 2003). The unemployment crisis requires an affirmative action in order to give the youth an opportunity. According to Semboja and Hatibu (2005), the major issue is to design the most integrated macroeconomic policies that develop a good opportunity for the youth. The researcher further acknowledges the fact that the youth are faced with numerous challenges but emphasizes that as members of the society the youth deserve full access to education, adequate health care, employment, financial services and participation in public life. Several countries in the world have therefore put in a lot of effort to address issues that affect the youth and ensure that they are involved in the planning, implementation and evaluation of development projects. In Britain, according to Trust Business program is all-round promoter of business new companies in the United Kingdom and was established in 1986 by the Prince of Wales to enable the youngsters to satisfy their potential. From that point, forward the Trust has turned into the UK driving youth philanthropy offering a scope of chances including preparing, self-improvement, business start-up bolster, tutoring and counsel. It targets people matured approximately 18 and 30 who are jobless or underemployed and have been denied saving money fund enabling them to set up their own business under the direction of a volunteer business tutor. In India, Bharatiya Yuva Shakti Trust, an open non-benefit association enables the youngsters to set up their own business by giving low intrigue credits preparing and guide bolster (Shankar, 2016).

In Malawi, according to the International Labour Organization (2002), his Excellency the state President Ngwazi, Professor, conceived the Youth Enterprise Development Fund in Malawi. Binguwa Mutharika as a vehicle to address challenges confronting youth in Malawi by furnishing them with learning, basic aptitudes skills and chances to take part in smaller scale little and medium endeavours as an independent work component. Subsidizing is required for loaning to the young, for their working capital needs, obtainment of instruments and hardware, preparing of adolescents in craftsman's and business administration abilities and re-equipment of training institutions. The Business leaders forum report (2012) points out that Uganda has one of the most astounding youth joblessness figures on the planet with work creation slacking fundamentally beneath the 300,000 who join the work compel, so the legislature of Uganda through the Ministry of back, arranging and financial advancement did launch a youth venture capital fund on 1st February 2012. The fund was meant to target start-up businesses and small to medium size enterprises. It was meant to expand the existence of business ventures owned by youths who were defined as persons aged between 18 and 35 years. In Tanzania, youth development rotating store was propelled in 1994 with the point of helping the young in the casual segment to make formal business and diminish youth joblessness (Christina, 2010). The government provided a mandate that all nearby government specialists must designate $5 \%$ of their income for youth improvement mostly in work and wage producing exercises. The national youth spinning reserve was set up to help youth pay creating exercises in sorted out financial generation detachments and little business entrepreneurs. Edwards (2007), states that in Kenya youth speak to $30 \%$ of the populace and their joblessness is double the nation's normal. Youth in Kenya confront genuine difficulties including high rate of 
joblessness and underemployment. Joblessness is not just caused by an absence of employments yet in addition an absence of occupation abilities because of insufficiency of preparing foundation and additionally the way to gain aptitudes because of neediness. It is in acknowledgment of the above truth that the administration considered the possibility of institutional financing as a method for tending to joblessness among the adolescent. The Youth Enterprise Development idea depends on smaller scale, little and medium undertaking improvement activities are probably going to have the greatest effect on work creation.

Youth Enterprise Development Fund (YEDF) Report (2010), points out that the Youth Enterprise Development Fund activities, which mainly involve the financing of youth enterprises, came legally into operation on 8th December 2006 through legal notice number 167. President Mwai Kibaki officially launched it on 1st February 2007. It was then transformed into a state corporation on 11th May 2007 through legal notice number 63. The fund emphasis in developing business as a key technique that will increment monetary open doors for and cooperation by the Kenyan youth in national building (YEDF Report, 2010). The command of the store is not just expanding access to capital by youthful business people yet additionally giving business improvement administrations, encouraging linkages in supply chains, making market openings locally and abroad for items and administrations of youth undertakings, and encouraging making of business foundation to help development of youth business. The report clarifies assist that, in acknowledgment of the way that not all youngsters are occupied with business, the assets order likewise incorporates encouraging work of semi-gifted and talented youngsters in outer work markets and involves encouraging travel documentation and financing expense of movement. Through Financial Intermediaries, the fund has financed 141,552 group and individual enterprises by Ksh 5.3 billion (Ochieng, 2014). The fund disbursed is expected to be repaid back to the lending institutions to be accessed by other youth enterprises that were unable to access the fund due to limited allocation by treasury. Through YEDF, the Government has released Kshs. 11,917,198 to 328 youth groups, no funding to individual members of the groups and Kshs. 83,702,926 disbursed to 2891 youths in Siaya County (Ochieng, 2014).

Youths are regarded as the most productive members of the society since they provide the workforce; the current situation is a disadvantage for Kenya. This is also the reason as why the formulation and implementation of the comprehensive youth development policies are not only considered a moral responsibility but also crucial for any meaningful national development. The high rate of unemployment remains one of the greatest challenges to Africa's development and therefore a major concern to policy makers and other stakeholders across Africa (Wanjiru, 2009). Due to lack of opportunities in the formal labour market, majority of youths are engaged in the informal sector that is largely unregulated and are subjected to hazardous conditions for low earnings and long working hours, without any formal contract. To empower youth's challenges, the Youth Enterprise Development Fund (YEDF) was introduced on 8th December 2006 and later formed into a State Corporation on 11th May 2007. In 2008 YEDF developed a three year strategic plan to address varied needs and aspirations of the youth, and to address the challenges it had faced in the past and was currently working on a 5 year strategic plan in line with the Medium Term Plan (MTP) of 15 the Vision 2030. The fund is constantly reviewing its operational mechanisms from time to time in order to make it responsive to needs and expectations of the youth. Its vision is to create a sustainable and growing fund, which would economically empower Kenyan Youth and their strategic partnerships. YEDF objectives include providing loans to youth owned enterprises, attracting and facilitating investment in micro, small and medium enterprises oriented commercial infrastructure that will be beneficial to youth enterprises, supporting youth oriented micro, small 
and medium enterprises to develop linkages with large enterprises, facilitating the marketing of products and services of youth enterprises both in the domestic and the international markets, providing business development services to youth enterprises, facilitating employment of youth in the international labor market.

YEDF in Kenya was established in 2006 with the sole purpose of reducing unemployment among the youth and was one of the flagship projects of Vision 2030 under the social pillar. The target of the fund was young people within the age bracket of 18 to 35 years and was gazette on 8th December 2006 and transformed into a State Corporation on 11th May 2007. Its strategic focus was on enterprise development as a key strategy to increase economic opportunities for the youth in nation building. The government has so far released Kshs. 11.9 billion to the Fund through the national treasury (YEDF Status Report 2016). Furthermore, the Youth Enterprise Development Fund booklet (2010), points out that the fund facilitates marketing of products and services of youth enterprises both in domestic and the international markets and provides business development services to young entrepreneurs and facilitates the employment of youth in the international labour market. It further states that the fund through its objectives has developed different products for young entrepreneurs, loans through financial intermediaries, the constituency youth enterprise scheme and the easy youth enterprise scheme, market products and market linkages, enterprise development services, jobs abroad and commercial infrastructure.

The YEDF Fund was established to accomplish the following; give advances to existing miniaturized scale fund establishments (MFIs), enlisted non-governmental organizations (NGOs) engaged with savings and credit co-operative organizations (SACCOS) for on-loaning to youth undertakings; pull in and encourage interest in smaller scale little and medium endeavours situated business foundation, for example, business or mechanical parks, markets or business hatcheries that will be useful to youth ventures. Besides, it has upheld youth MSEs to create business linkages with MLEs; encourage advertising of items and administrations of youth endeavours in both household and universal markets; and give enterprise preparing to youth enterprises (YEDF, 2013). The YEDF achieved the following results for the past five years, more than 157,000 youths enterprises have been awarded approximately KES 5.9 Billion. The money has played a vital role in training at least 200,000 youths, creating employment opportunities to more than 300,000 people. The fund has also helped more than 6000 youths to secure employment in other countries. More than 1800 youth's groups have been helped in advertising their products in local market and 32 at regional level, at least 2500 youths have undergone training to improve their business skills (Kenya Country report, 2014). It is important to note that the fund has played an imperative role in improving youth entrepreneurial skills as well as understanding lending capacity.

\section{STATEMENT OF THE PROBLEM}

Youth empowerment is vital for any nation. Most Kenyan youths aspire to get white-collar jobs after completing education in order to build self and the nation. To most, achieving their career goals after the 8-4-4 education system is the most critical thing hence they will not settle for anything less than what they have trained for. The Government of Kenya has made efforts over the years to empower the youth by coming up with policies that enable the youth to venture in education as well as create opportunity for income generating projects (Nyongesa, 2014). Indeed, in 2006 The Government of Kenya established Youth Enterprise Development Fund with overall purpose of creating employment for the youth through enterprise development. The fund seek to empower the youth, age $18-35$ years, by providing loans and business development services to youth enterprises, supporting youth-oriented micro, small and medium enterprises to develop links 
with large enterprises (YEDF, 2013). In October 2016, Wajir County disbursed Ksh 27 million to youth groups and this entire amount was not recovered. This implies that the projects and business initiated by the youths are not performing well to permit the loan servicing (Nairobinews 2016). Despite the continued increase in financial support to youth enterprises by the government and other development agents, there is still a chronic failure and collapse rate of youth projects in Kenya. The YEDF loan repayment level in Wajir County is below $20 \%$. This revolving fund then faced high risks of extinction, yet it was meant to be revolving among the youth while empowering them.

While the effort of the government is commendable and well meaning, it does not always work to expectations. Joblessness and underemployment have been distinguished as Kenya's most troublesome and tenacious issues. Around $12.7 \%$ of the working age populace is jobless. Around $67 \%$ of Kenya's jobless are youth approximately 18 and 34 years old. The most elevated joblessness rates are for individuals around 20 years of age at 35\% (KDHS, 2009). More than one million youths go into the work advertise every year with no aptitudes, some having either dropped out of school or finished school and not selected in any school. Despite the availability of data on loan disbursement to youth groups, there is no reliable information on the levels of youth empowerment resulting from YEDF loan disbursement and entrepreneurship training conducted to the youth, yet it is the empowerment of the youth that should form the basis of sustained funding of YEDF. Most studies have focused on the funding structure that acts as the source of income. The monitoring of the disbursement of the funds is suspect while that of the fund's impact among the beneficiaries is wanting. It is on this basis that this study therefore seeks to examine the effects of YEDF services on youth empowerment in Wajir County.

\section{GENERAL OBJECTIVE}

The general objective was to evaluate the effect of youth enterprise development funds services on youth empowerment in Wajir County, Kenya.

The specific objectives were:

i. To assess the effect of YEDF entrepreneurial training on youth empowerment in Wajir County, Kenya.

ii. To examine the effect of YEDF provision of loans on youth empowerment in Wajir County, Kenya

iii. To determine the effect of YEDF provision of market linkages on youth empowerment in Wajir County, Kenya

\section{THEORETICAL LITERATURE REVIEW}

This section is an attempt to theorize or make logical sense of the relationship among the various factors that have been identified as important to the study problem.

\subsection{Social Capital Theory}

While different meanings of social capital are advanced in writing, this investigation will centre on the definitions considered pertinent for monetary purposes and that allude to a typical essential thought: informal organizations are profitable resources. As indicated by Bourdieu (1983/1986) "Social capital is the total of the genuine or potential assets which are connected to ownership of a sturdy system of pretty much systematized connections of shared associate and acknowledgment" (p. 248). Social capital, as such, constitutes social commitments and associations within members in a group (Lin, 2001). Coleman (1988) stated, "Social capital is 
characterized by its capacity. It's anything but a solitary element, yet a wide range of elements, having two attributes in like manner: they all comprise of some part of a social structure, and they encourage certain activities of people who are inside the structure" (p. S98). Overall, Coleman (1990) featured that social capital demonstrates the assets, genuine or potential, picked up from connections. It is an open decent, and accordingly it relies upon the ability of the individuals from the network to stay away from free riding. For this reason, standards, trust, endorses and values wind up essential in supporting this aggregate resource. Putnam (2000) featured that "While physical capital alludes to physical articles and human capital alludes to the properties of people, social capital alludes to associations among people - interpersonal organizations and the standards of correspondence and reliability that emerge from them" (p. 19). Putnam underscored that "a general public of numerous prudent however detached people isn't really rich in social capital". Albeit all the past definitions portray the idea from alternate points of view, they in any case display a typical view: it is the communications between individuals that make conceivable the creation and upkeep of this social resource. As indicated by Morton and Montgomery (2011), the hypothesis stresses the part of strengthening encounters in encouraging both feeble and solid systems that increase youngsters' flexibility and their capacity to get to new aptitudes, support and assets that advance networks that are more beneficial and person's financial versatility. They clarify that these associations are encouraged by the young and grown-ups who constitute the fundamental strengthening forms. Mcguire (2012), states that this hypothesis depends on the idea of production of systems and affiliations that work to construct associations that can be changed over to financial capital and associations created through well off grown-ups and frameworks.

Ricardo (2010) clarifies that social capital hypothesis includes distribution of assets and key types of institutional help installed in multi-layered frameworks of social structure starting with a major system. He refers to cases of these associations as connections, systems and relationship as a web based life, which thusly is installed in formal and complex associations and foundations. The social structures, he insinuates, comprise of positions that have diverse assets that are various levelled and offer certain qualities and techniques in the utilization of assets that are depended to institutional specialists who follow up on these guidelines and strategies. He clarifies that these principles of social structure encourage a type of solidarity and participation in network among the individuals who involve comparable area in the chain of command in this manner the performers can associate with other ingenious gatherings by actuating social structures, holding fast to the guidelines of pecking order, distinguishing their area in the bigger social association and building up authentic connections. It is based on this social structure that performing artists can propel the venture procedure in more personal levels that facilitate accomplishment of personal and collective goals. In the context of Youth Enterprise Development Fund, social capital theory relates closely to the idea of establishing the fund. The Youth Enterprise Development Fund requires that all beneficiaries must be youths who belong to organized groups or entities that share same business values which must be registered by relevant government bodies (Government of Kenya, 2011). YEDF supports these groups by organizing market linkages through which the groups can form connections that facilitate marketing of their products and services. In addition, entrepreneurial trainings and youth friendly loans ensure that the youth possess business development skills and financial resources respectively that enhance their capacity to establish and strengthen successful business ventures that ultimately improves their livelihood (Ministry of Youth Affairs, 2006). 


\subsection{Theory of Change}

Theory of Change (ToC) is an approach for arranging, investment, and assessment that is utilized as a part of charity, not administrative and government segments to help social change. ToC depicts long haul objectives and after those maps in reverse to recognize essential preconditions (Brest, 2010). ToC created from the fields of program hypothesis and program assessment in the mid1990s as another method for breaking down the speculations spurring projects and activities working for social and political change (Weiss, 1995). The hypothesis not just spotlights on creating learning concerning whether a program is powerful, yet in addition on depicting the techniques it uses to be successful (Coryn et. al, 2011). Inside assessment rehearse, ToC rose in the 1990s at the Aspen Institute Roundtable on Community Change as a way to display and assess far-reaching network activities. The Roundtable's initial work focused on working through the difficulties of assessing complex network activities. This work finished in a distribution called, 'New Approaches to Evaluating Comprehensive Community Initiatives' (Weiss, 1995). Weiss theorized that a key reason complex projects are so hard to assess is that the suppositions that move them are ineffectively enunciated. She contended that partners of complex network activities regularly are indistinct about how the change procedure will unfurl and along these lines put little consideration on the early and mid-term changes expected to achieve a more extended term objective.

Weiss advanced the expression "Hypothesis of Change" as an approach to depict the arrangement of suspicions that clarify both the smaller than normal advances that prompt the long haul objective of intrigue and the associations between program exercises and results that happen at consistently. She tested planners of complex network based activities to be particular about the hypotheses of progress managing their work and proposed that doing as such would enhance their general assessment designs and would fortify their capacity to assert credit for results that were anticipated in their hypothesis. Weiss' recommendation was to lay out the arrangement of results that are relied upon to happen as the consequence of an intercession, and plan an assessment technique around following whether these normal results are really delivered. As per Morton and Montgomery (2011), the hypothesis of progress includes programs that seek to create basic mental resources among the taking an interest adolescents that incorporate strong connections, asserting condition, and abilities advancement. Reinsh (2012) noticed that the hypothesis includes a blend of money related training, social/jobs instruction and budgetary incorporation as a methods through which the young can accomplish socio-monetary capacity and at last financial citizenship. He takes note of that such strengthening suggests that the adolescent have expanded certainty and viability in controlling their lives and asserting their rights. He reasons that the hypothesis centers around more noteworthy monetary citizenship accomplished through thrift where capable monetary and city commitment advances diminishment in destitution, supportable job and money related prosperity. The YEDF concept heavily borrows on change theory as it combines entrepreneurial education and provision of loans to youth groups and entities as means through which the youth can ultimately achieve economic empowerment, thus manage their lives, and actively participate in national development (Government of Kenya, 2011).

\subsection{Reform Theory}

The theory as explained by Cooper and White (1994), states that young people are socially disadvantaged by their environment and upbringing and therefore become outcast and this causes them to inflict violent behaviours on themselves and others. The theory maintains that the society has values that are acceptable and desirable but some changes (reforms) on the values may be 
necessary to improve condition of the disadvantaged groups and therefore the theory advocates for interventions that will primarily ensure social stability by supporting the process of equal participation of the youth in the community. The theory suggests that the society must provide education, training and specific programs and services that target the needs of the young people.

The Youth Enterprise Development Fund relates well with the reform theory on youth empowerment as it is a government of Kenya strategic policy toward arresting youth challenges that includes unemployment, underemployment, crime, drug abuse, lack of capital, among others, that make them vulnerable (Odhiambo, 2012). The fund thus provides accessible, affordable and youth friendly credit facilities in addition to providing capacity building training on enterprise development among the youth as a means through which they can achieve economic empowerment and ultimately become responsible citizens.

\section{CONCEPTUAL FRAMEWORK}

A Conceptual framework is a set of broad ideas and principles from relevant fields of inquiry and used to structure a subsequent presentation according to Kombo and Tromp (2005). It explains the relationship that exists between independent and dependent variables. The study sought to find out the effects of YEDF entrepreneurial training, YEDF provision of loans and YEDF provision of market linkages to youth enterprises on youth empowerment in Wajir County.

\section{Independent variables}

\section{Dependent variable}

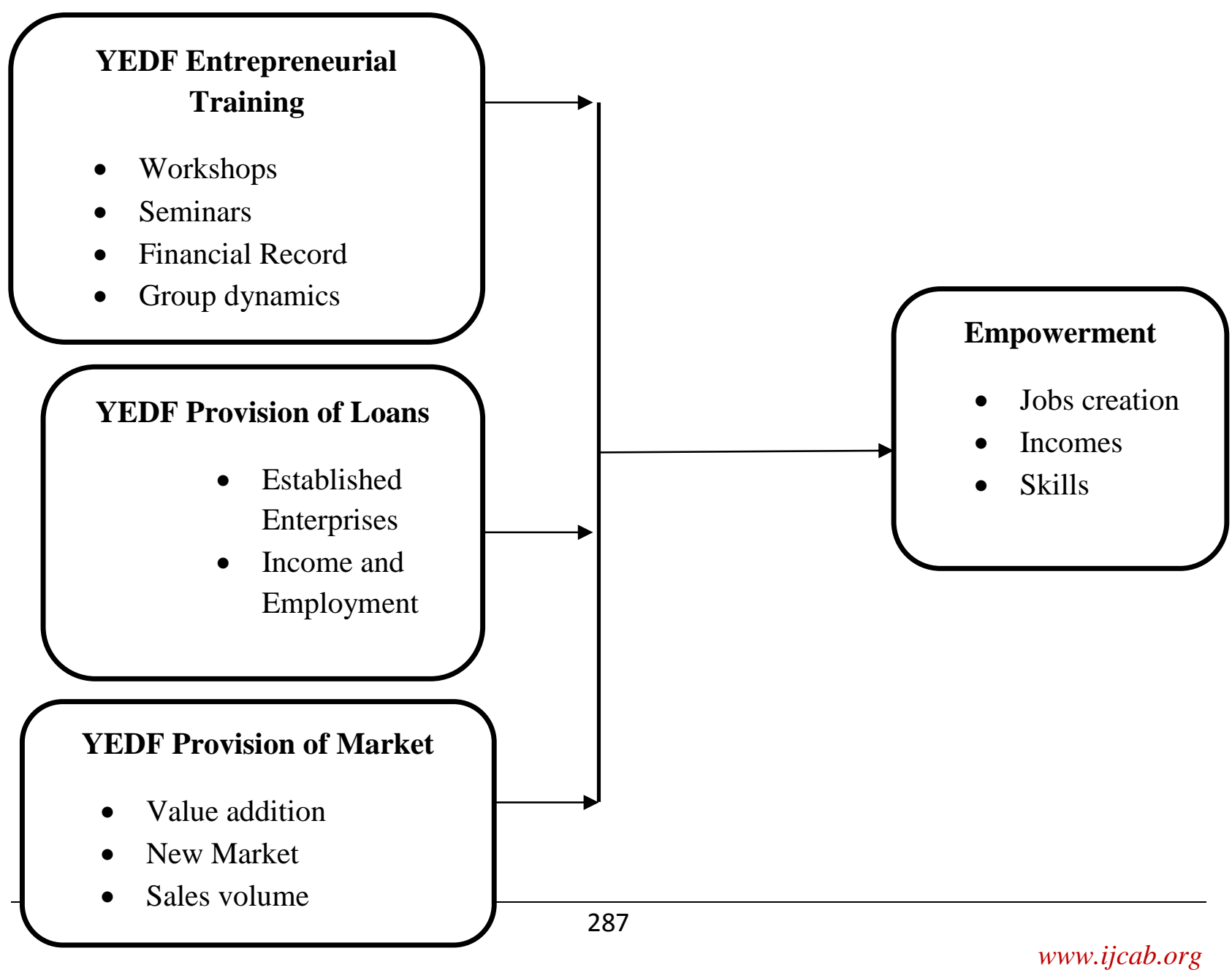


Figure 1: Conceptual Framework

lent Fund

services are hypothesized to have an effect on youth empowerment amongst youth in Wajir County. The Youth Enterprise Development Fund services are outlined as entrepreneurial training, provision of loans and provision of market linkages.

\section{RESEARCH METHODOLOGY}

The current study adopted descriptive survey, these includes the survey and inquiries that helps in describing the real issues (Kothari, 2006). The descriptive research design was appropriate in allowing the researcher to assess the target population as well as determining factors under the investigation. The target population of the study comprised 200 youth groups in Wajir County, which are involved in small businesses in towns and are mostly funded by YEDF (County Government of Wajir, 2016). The research adopted simple random sampling strategy to select 30 percent of the Youth Groups according to Orodho (2005) for the sample of this research. Therefore, the sample size of $\frac{30}{100} * 200=60$ youth groups was considered the sample size for the study. In each selected group one of the three official namely chairman, secretary or treasurer that were purposively selected. Both primary and secondary data was collected in the study. Primary data was collected via questionnaires (structured and unstructured questionnaires). Secondary data was collected from reviewed literature from journals, relevant books, and YEDF reports. The researcher was available to assist the respondents to understand the areas that are not clear for high response rate. Purpose of the study was explained to the respondents during data collection. Data for the study was collected from the youth owned enterprises which had accessed the Youth Enterprise and Development Fund within Wajir County. After the questionnaires were completely filled, they were edited for accuracy. The data was coded and entered on a Statistical Package for Social Science (SPSS) software that aids in analysis of both qualitative and quantitative data. The researcher adopted content analysis to analyse the qualitative data based on the objectives. The descriptive statistics was used in analysing quantitative data. In analysing the relationship between variable (YEDF services and youth empowerment) the study used regression analysis. The findings were presented inform of tables and graphs.

\section{DATA ANALYSIS RESULTS}

This section presents a summary of regression analysis between the independent variables including entrepreneurial training, YEDF provision of loans and market linkages and a dependent variable namely the youth empowernment. The regression model shows the strength of the relationship between our study variables. The second table shows the Anova results that determined the significance relationship between the variables while the regression coefficient revealed the regression coefficient of all variables.

Table 1: Regression Model Summary

\begin{tabular}{llll}
\hline Model & R Square & Adjusted R Square Std. Error of the Estimate
\end{tabular}

\begin{tabular}{lllll}
\hline & $.675^{\text {a }}$ & .456 & 0.645 & .123
\end{tabular}


International Journal of Current Aspects, Volume 3, Issue II, 2019, PP 280-292, ISSN 2616-6976

[IJCAB

a. Predictors: (Constant), entrepreneurial training, YEDF provision of loans and market linkages

From the model summary above the $R$, value (coefficient of determination) represents the fitness of the regression model. $\mathrm{R}$ square is 0.645 , this means entrepreneurial training, YEDF provision of loans and market linkages and youth empowernment expalin 64.5 of the variations in the dependent variable which is youth empowerment in Wajir county. This further explains that the model applied to determine the relationship of the variables was satisfactory.

Table 2: ANOVA Results

\begin{tabular}{|c|c|c|c|c|c|c|}
\hline Model & & Sum of Squares & $\mathrm{Df}$ & Mean Square & $\mathrm{F}$ & Sig. \\
\hline & Regression & 258.284 & 4 & 64.571 & 130.446 & $.007^{\mathrm{b}}$ \\
\hline & Residual & 27.204 & 55 & .495 & & \\
\hline & Total & 285.487 & 59 & & & \\
\hline
\end{tabular}

a. Dependent Variable: youth empowernment

b. Predictors: (Constant), entrepreneurial training, YEDF provision of loans and market linkages

The ANOVA Table indicates that entrepreneurial training, YEDF provision of loans and market linkages, significantly predict youth empowernment as shown by the $\mathrm{P}$ value which is $<0.05$.

Table 3: Regression Coefficients

$\begin{array}{lllll}\text { Model } & \text { Unstandardized Coefficients } & \begin{array}{l}\text { Standardized } \\ \text { Coefficients }\end{array} & \mathrm{t} & \text { Sig. }\end{array}$

B Std. Error Beta

\begin{tabular}{lccccc}
\hline Constant) & -1.282 & .275 & & -4.664 & .000 \\
$\begin{array}{l}\text { Obj 1: Entrepreneurial } \\
\text { training }\end{array}$ & .305 & .178 & -.225 & -1.709 & .092 \\
$\begin{array}{l}\text { Obj 2: YEDF provision } \\
\text { of loans }\end{array}$ & .319 & .175 & .130 & 1.826 & .072 \\
Obj 3: Market linkages & .863 & .148 & .712 & 5.838 & .010 \\
\hline
\end{tabular}

a. Dependent Variable: Youth Empowernment

The Coefficients Table provides us with a Constant $\left(\beta_{0}\right)$ (1.282) and the co-efficient of entrepreneurial training variable (.305), YEDF provision of loans (0.319), Monitoring and Evaluation (0.863) and market linkages (0.765) which helps in formulation of the linear regression equation. The regression analysis reveals that entrepreneurial training contributes $30.5 \%$, YEDF provision of loans $31.9 \%$, market linkages contribute $86.3 \%$ to youth empowernment. The study reveals that there is positive association between entrepreneurial training and the youth empowernment. This implies that when youths are trained they gain more knowledge about 
business activiites. This supports the study done by Adegun (2013) in his study revealed that entrepreneurship education has a significant impact on youth empowerment in Nigeria, youths tends to have innovative response in economic and social ventures that involves setting up business ventures through willingness and ability of an individual to explore investment opportunities and being able to run it successfully through making it profitable or suffering loss of invested capital.

The study also revealed that there is positive association between YEDF provision of loans and youth empowernment in Wajir County. The findings support the study done by Johnson and Rogaly (1997) who found out that the provision of loan has an impact on minimizing poverty and promoting their business activities. The study conducted by Ahaibwe (2014) on creating youth employment through entrepreneurship notes that the Government of Uganda in 2011 in partnership with DFCU Bank, Stanbic Bank and Centenary Bank revealed that Youth Venture Capital Fund helps in growing of viable and sustainable Small and medium enterprises by youth in private sector aimed at addressing youth unemployment through job creation, business expansion and business skills development. The study finally found out that there is a signifiant relatihsip between market linkages and the youth empowernment. Jenkins and Ishikawa, (2009) in their study found out that market linkages have a significant effect on youths' empowerment. Their study also found out that the participation as suppliers, distributers or retailers in commercial value chains can help to increase local jobs and wealth creation, enhanced skill and capacity, purchasing power and generally stimulate economic activity and development thus improving the quality of life. The program has made many youths to engage in business and coming up with ways of attracting customers.

\section{CONCLUSIONS}

From the summary of findings, the study concludes that attending the entrepreneurship training is important in improving business performance. The youths are trained on ways of improving and retaining customers. The study also concludes that entrepreneurship training has a significant impact on the youth empowerment. The study concluded that most youths in the county have loan accessibility and have been accessing it for the past one year. The loan was given to the groups with an aim of improving the business activities. The study also concludes that provision of loans has encouraged youths to engage in business and there is a significant relationship between the loan provision and youth's empowerment. The findings also concluded that most youths have attended market linkages program. By attending the programs, they have learnt various ways of improving their business performance and sharing of business ideas. Finally, the study concludes that there is a significant relationship between market linkages and youth's empowerment in the County.

\section{RECOMMENDATIONS}

Based on the findings, the researcher proposed the following recommendations to enhance youth empowerment in Wajir County and the country by extension; Entrepreneurship training should be continuous and sensitization increased for the youth to attend the trainings to equip them with business skills and knowledge to enable them manage their business successfully. Start-up loans should be increased and measures put in place to enhance their accessibility so as to provide employment to the youth, enhance their income and thereby improving their living standards. YEDF should come up with youth tailor-made programmes that will go a long way in assisting the young entrepreneurs make use of market opportunities and link them to value chains. 


\section{REFERENCES}

Bourdieu, P. (1983/1986). "The Forms of Capital": Handbook of Theory and Research for the Sociology of Education, edited by J.G. Richardson. Westport, CT: Greenwood Press.

Brest, P. (2010). The power of theories of change. Stanford Social Innovation Review, 8(2), 4751.

Business Leaders Forum (2012). The Business of Enterprises; Meeting the Challenge of Economic Development through business and community partnerships.

Christina, D. J. (2010). Uganda Youth Fund is a useful start, Report of the Danish Council.

Coleman, S. J. (1988). "Social Capital in the Creation of Human Capital" American Journal of Sociology. Vol. 94 pp. S95-S120.

Coleman, S J 1990 Foundations of social theory, Cambridge: Harward University Press

Coryn, C. L., Noakes, L. A., Westine, C. D., \& Schröter, D. C. (2011). A systematic review of theory-driven evaluation practice from 1990 to 2009. American journal of Evaluation, 32(2), 199-226.

County Government of Wajir. (2016). Annual Devlopment Plan 2015/2016. Retrieved from:http://www.wajir.go.ke/UserSiteFiles/publicDocs/WAJIR\%20ADP\%20FY201516.pdf

Edwards, G. (2007). The Role of Banks in Economic Development. The European Observatory for SMEs. London, Macmillan.

International Labor Organization (2002). Decent work and informal economy

International Labour Organization (2010). An Introductory Guide for Employers' Organizations: Tackling Youth Employment Challenges. 1st Edition, Italy: International Centre of the ILO International Labor Organization (1985), Informal sector in Africa. Addis Ababa, Ethiopia: Jobs and Skills Programme for Africa.

Lin, N. (2001). Social Capital a theory of Social structure and Action. Cambridge: Cambridge University Press.

Lin, F. (2013).Youth Bulge: A Demographic dividend or Demographic Bomb in Developing countries. Washington, DC: Washington Publishers.

Mcguire, A. (2012). Social capital development in youth development programming: a case study of California 4-H, Youth, Families and community youth development programs. Los Angeles: California University of California.

Ministry of Youth Affairs. (2006).Kenya National Youth Policy. Nairobi: Ministry of Youth Affairs.

Morton, M. \& Montgomery, P. (2011). Youth empowerment programs for improving self-efficacy and self-esteem of adolescents. Oxford: University of Oxford.

Mugenda, M. \& Mugenda, A. G. (1999). Research Methods: Quantitative and Qualitative Approaches. Nairobi: Acts Press.

NCCK, (2012).Demographic Transition and Youth Bulge, The Case of Kenya. Nairobi: NCCK.

Nicole A. (2001) "Promoting Adolescent Livelihoods Discussion Paper Prepared for Common. Wealth Youth Programme and UNICEF", New York, U.S.A.

Odhiambo, O (2006). Enhancing the Production Capacity of Rural Youth in Agriculture. Environment and Natural Resource Management towards Employment Creation in. Kenya: experiences for Kenya Rural Youth Livelihood Strategies

Odhiambo, O. (2013).Effect of the Youth Enterprise Development Fund on Youth Enterprises in Kenya, School of Business and Economics. Kisumu: Maseno University. 
Orodho J. A., (2005). “Techniques of Writing Research Proposal and Reports in Education and Social sciences.” Nairobi: Kanezja HP Enterprises

Putnam, R. D. (2000). Bowling Alone: the collapse and revival of American community, Simon $\&$ Schuster, New York.

Reinsh, M. (2012). Youth Financial Inclusion: Promising Examples of achieving youth economic empowerment. London: European Microfinance Project.

Republic of Kenya (2010).The Constitution of Kenya. Nairobi: Government Printer.

Ricardo, D. (2010). Social capital framework for the study of institutional agents and theories. Charlotte: University of Carolina.

Semboja, H \& Hatibu, H (2005). A concept paper on promoting opportunities for youth employment in East Africa, prepared for the ILO regional office and presented at the EAC meeting of labour commissioners, Silver springs Hotel, Nairobi, Kenya.

Shankar, R. K. (2016). Bharatiya Yuva Shakti Trust. Institutional Case Studies on Necessity Entrepreneurship, 57.

The Prince Scottish Youth Business Trust, (2004). Reflecting on the 15 years of PSYBT. Annual Report.

Thiongo, N. M (2003). The World Youth Report: The Global Situation of Young people.

United Nations Development Program. (2009). Kenya Human Development Report, Youth and Human Development, Tapped on the untapped resources. Nairobi: United Nations Development Program.

United Nations Development Program. (2013).Kenya's Youth Employment Challenge. Nairobi: United Nations Development Program.

Weiss, C. H. (1995). Nothing as practical as good theory: Exploring theory-based evaluation for comprehensive community initiatives for children and families. New approaches to evaluating community initiatives: Concepts, methods, and contexts, 1, 65-92.

Youth and African Youth commission. (2006).Africa Youth Charter. Addis Ababa. Ethiopia: Youth and African Youth commission.

Youth Enterprise Development Fund (2009). EDA Training Booklet, Capacity Building Program For MOYA Officers

Youth Enterprise Development Fund Booklet (2010). Three years of youth Fund

Youth Enterprise Development Fund Report (2010). Three years of the Youth Fund, NAIROBI

This is an open-access article published and distributed under the terms and conditions of the $(\mathrm{cc}) \mathrm{EY}$ Creative Commons Attribution 4.0 International License of United States unless otherwise stated. Access, citation and distribution of this article is allowed with full recognition of the authors and the source.

Authors seeking to publish with an International Peer Reviewed Journal should consider www.ijcab.org by writing to the Editor at editor@ijcab.org. List of our Journals are Available at www.ijcab.org/journals 